\title{
Lung Tissue Drug Concentration
}

National Cancer Institute

\section{Source}

National Cancer Institute. Lung Tissue Drug Concentration. NCI Thesaurus. Code C129954.

The level of drug in lung tissue, expressed as a concentration. 